\title{
PEMBELAJARAN BERBASIS STUDENT-CENTERED LEARNING PADA MATERI PENDIDIKAN AGAMA ISLAM
}

\author{
Zulvia Trinova \\ Dosen Fakultas Tarbiyah dan Keguruan IAIN Imam Bonjol Padang \\ e-mail: zulvia.trinova12@gmail.com
}

\begin{abstract}
A professional teacher - the one who does not only master the subject, but also be competent in selecting certain model - is really needed to carry out the teaching and learning process. One of the alternative learning models that may activate students is Student-Centered Learning (SCL). This model provides students with the opportunity to actively participate independently in his learning, be responsible and initiate to his learning needs.
\end{abstract}

Key words: student-centered, Islamic lesson, learning need

\begin{abstract}
Abstrak: Dalam melakukan pembelajaran dibutuhkan seorang guru yang profesional, tidak hanya profesional dibidangnya saja tapi juga profesional dalam memilih model pembelajaran. Salah satu alternatif model pembelajaran yang memungkinkan dikembangkannya keaktifan setiap siswa adalah Pembelajaran Berbasis Student Centered Learning (SCL). Dalam menerapkan konsep Student Centered Leaning (SCL), siswa dapat berperan aktif dan mandiri dalam proses belajarnya, yang bertanggung jawab dan berinisiatif untuk mengenali kebutuhan belajarnya. Dengan selalu berpegang pada nilai-nilai budaya, yang relevan dan sesuai dengan nilainilai Islam, maka pembelajaran PAI yang dilakukan dengan model Student Centered Learning (SCL), dengan mengimplementasikan pendidikan Islam menjawab pembentukan manusia yang kompeten dalam kehidupannya sebagai khalifah di bumi.
\end{abstract}

Kata Kunci: Student Centered Learning (SCL), Pendidikan Agama Islam, kebutuhan mahasiswa

\section{PENDAHULUAN}

Pendidikan dapat diartikan sebagai bimbingan atau pertolongan yang diberikan dengan sengaja terhadap anak didik oleh orang dewasa agar ia menjadi dewasa. Dalam perkembangan selanjutnya, pendidikan berarti usaha yang dijalankan oleh seseorang atau sekelompok orang untuk mempengaruhi seseorang atau sekelompok orang agar menjadi dewasa atau mencapai tingkat hidup dan penghidupan yang lebih tinggi (mental). Dengan demikian pendidikan berarti segala usaha orang dewasa dalam pergaulan dengan anak-anak untuk memimpin perkembangan jasmani dan rohaninya ke arah kedewasaan.

Pendidikan menurut Undang-undang No.20 Tahun 2003 tentang Sistem Pendidikan
Nasional (SISDIKNAS) adalah usaha sadar dan terencana untuk mewujudkan suasana belajar dan proses pembelajaran agar peserta didik secara aktif mengembangkan potensi dirinya untuk memiliki kekuatan spritual keagamaan, pengendalian diri, kepribadian, kecerdasan, akhlak mulia, serta keterampilan yang diperlukan dirinya, masyarakat, bangsa, dan negara.

Pemerintah mengeluarkan Undangundang No. 20 Tahun 2003 tentang Sistem Pendidikan Nasional yang menyatakan bahwa: Pendidikan Nasional berfungsi mengembangkan kemampuan dan membentuk serta peradaban bangsa yang bermanfaat dalam rangka mencerdaskan kehidupan bangsa bertujuan untuk berkembangnya potensi peserta didik agar 
menjadi manusia beriman dan bertaqwa kepada tyuhan yang maha esa, berakhlak mulia, sehat, berilmu, cakap, kreatif, mandiri dan menjadi warga negara yang demokratis serta bertanggung jawab. (Oemar Hamalik: 2009, h. 131-132)

Tujuan pendidikan di atas diwujudkan melalui proses pendidikan. Oleh karena itu pendidikan memegang peranan penting dalam mengembangkan potensi yang telah dimiliki oleh manusia dan pendidikan merupakan wahana mendapatkan ilmu pengetahuan. Tujuan pendidikan dapat menjadikan peserta didik beriman dan bertaqwa kepada Tuhan Yang Maha Esa serta menjadi diri yang bertanggung jawab, setiap pendidikan akan membekali peserta didik dengan ilmu untuk masa depan yang diarahkan untuk meningkatkan kualitas manusia melalui olah batin (aspek transendensi), olah pikir (aspek kognisi), olah rasa (aspek afeksi), dan olah kinerja (aspek psikomotoris) agar memiliki daya saing dalam menghadapi tantangan global.

Pendidikan merupakan tolak ukur kemajuan suatu bangsa bahkan pendidikan merupakan alat untuk menguasai dunia. Penjelasan tersebut telah dijelaskan oleh Allah SWT dalam Q.S Ar. Rahman ayat 33, yang artinya: "hai jama'ah dan manusia, jika kamu sanggup menembus (melintasi) penjuru langit dan bumi, maka lintasilah, kamu tidak dapat menembusnya kecuali dengan kekuatan". (Departemen Agama RI, Al- 'Alliy, 2000, h.425)

Penjelasan ayat tersebut dapat dipahami bahwa besarnya peranan pendidikan dalam proses perubahan dunia menuju kehidupan yang membahagiakan. Sedangkan dalam perspektif Islam ilmu pengetahuan sangat penting dan Islam menempatkan umatnya yang berilmu pada posisi yang mulia. Hal ini terdapat dalam Q.S Al-Mujadilah ayat 11, yang artinya: "Hai orangorang beriman apabila dikatakan kepadamu: "berlapang-lapanglah dalam majlis", maka lapangkanlah niscaya Allah akan memberikan kelapangan kepada kamu, dan apabila dikatakan: "berdirilah kamu", maka berdirilah, niscaya Allah akan meninggikan orang-orang yang beriman di antara kamu dan orang-orang yang diberi ilmu pengetahuan beberapa derajat. Dan
Allah Maha Mengetahui apa yang kamu kerjakan".

Penjelasan firman Allah tersebut telah dijelaskan bahwa Allah SWT akan meninggikan derajat orang berilmu. Mereka memiliki derajatderajat yang lebih tinggi yakni lebih tinggi dari sekedar beriman. Tidak disebutkan bahwa kata meninggikan itu sebagai isyarat bahwa sebenarnya ilmu yang dimiliki itu yang berperan besar dalam ketinggian derajat yang diperolehnya, bukan akibat faktor dari luar ilmu tersebut.

Untuk mencapai tujuan pendidikan nasional maupun tujuan pendidikan agama Islam maka ditentukan oleh proses pembelajaran. Pembelajaran dan pendidikan erat kaitannya dengan guru (pendidik) dan siswa (peserta didik).

Seringkali dalam proses pembelajaran Pendidikan Agama Islam materi tidak sejalan dengan kenyataan yang dihadapi oleh siswa. Padahal proses pendidikan sesungguhnya dijalankan dalam rangka memenuhi kebutuhan akan sumber daya manusia yang (minimal) sanggup menyelesaikan persoalan yang dihadapinya. Artinya, setiap proses pendidikan seharusnya mengandung berbagai pelajaran yang signifikan dengan kebutuhan masyarakat. Sehingga output pendidikan adalah manusia yang sanggup untuk memetakan dan sekaligus memecahkan masalah yang sedang dihadapi oleh masyarakat berdasarkan kemampuan yang diperoleh.

Pelaksanaan pembelajaran di sekolah, yang lebih banyak menggunakan metode konvensional, mengakibatkan siswa kurang terlibat secara aktif dalam kegiatan pembelajaran. Siswa cenderung hanya mendengar dan menerima penjelasan dari guru tanpa diberi kesempatan untuk mengutarakan pendapatnya secara luas dan terbuka. Kondisi seperti ini dapat dikatakan tidak memberdayakan para siswa mau dan mampu berbuat untuk memperkaya belajarnya (learning to do) dengan meningkatkan interaksi dengan lingkungannya. Sehingga tidak akan bisa membangun pemahaman dan pengetahuan terhadap dunia sekitarnya (learning to know). 
Lebih jauh lagi mereka pun tidak memiliki kesempatan untuk membangun pengetahuan dan kepercayaan dirinya (learning to be), maupun kemampuan berinteraksi dengan berbagai individu atau kelompok yang beragam (learning to live together) di masyarakat.

Sehubungan dengan hal di atas guru pendidikan agama Islam dapat mengembangkan model pembelajaran yang mampu meningkatkan kompetensi peserta didik baik dalam pemahaman mengenai ajaran-ajaran agamanya, mendorong mereka untuk mengamalkannya dan sekaligus dapat membentuk akhlak dan kepribadiannya. Belajar akan lebih bermakna (meaningful learning) jika anak mengalami apa yang dipelajarinya, bukan mengetahuinya. Pembelajaran yang berorientasi target penguasaan materi terbukti berhasil dalam kompetensi mengingat dalam jangka pendek, tetapi gagal dalam membekali anak memecahkan masalah dalam kehidupan jangka panjang.

Guru dituntut dapat memilih model pembelajaran yang dapat memacu semangat setiap siswa untuk secara aktif ikut terlibat dalam pengalaman belajaranya. Salah satu alternatif model pembelajaran yang memungkinkan dikembangkannya keaktifan setiap siswa adalah Pembelajaran Berbasis Student Centred Learning (SCL).

Dalam mencapai keberhasilan proses pembelajaran khususnya dalam pendidikan agama Islam, sangat ditentukan oleh profesionalitas guru agama yang salah satu indikatornya adalah guru diharapkan dapat mengembangkan dan menciptakan model dalam kegiatan belajar mengajar terutama dalam mata pelajaran pendidikan agama Islam, agar mata pelajaran Pendidikan Agama Islam lebih menarik dan menyenangkan bagi peserta didik.

Perubahan paradigma dalam proses pembelajaran yang tadinya berpusat pada guru (teacher centered) menjadi pembelajaran yang berpusat pada siswa (student centered) diharapkan dapat mendorong siswa untuk terlibat secara aktif dalam membangun pengetahuan, sikap dan perilaku. Melalui proses pembelajaran dengan keterlibatan siswa ini berarti guru tidak mengambil hak anak untuk belajar dalam arti yang sesungguhnya. Dalam proses pembelajaran yang berpusat pada siswa, maka siswa memperoleh kesempatan dan fasilitasi untuk membangun sendiri pengetahuannya sehingga mereka akan memperoleh pemahaman yang mendalam (deep learning), dan pada akhirnya dapat meningkatkan kualitas peserta didik.

Salah satu strategi pembelajaran yang tepat untuk dapat mendukung kualitas peserta didik adalah model pembelajaran student centered learning (SCL). Istilah student centered learning (SCL) merupakan suatu model pembelajaran dalam dunia pendidikan dan pengajaran dimana di dalamnya siswa memiliki tanggung jawab beberapa aktivitas penting seperti perencanaan, pembelajaran, interaksi antara guru dan siswa, penelitian dan evaluasi terhadap pembelajaran yang telah dikerjakan.

\section{PEMBELAJARAN BERBASIS STUDENT CENTERED LEARNING}

Proses pembelajaran secara konvensional menempatkan guru sebagai sumber belajar yang mengajarkan pengetahuan dan keterampilan kepada siswa. Perkembangan penelitian mengenai bagaimana seseorang belajar mempengaruhi proses pembelajaran konvensional yang menempatkan guru sebagai pusat belajar. Kunci perubahan tersebut terdapat pada pemikiran bahwa siswa secara aktif membentuk pengetahuannya sendiri, yang dikenal sebagai pemikiran kontruktivisme. Pendekatan kontruktivisme tersebut dalam implementasinya melahirkan pendekatan student centered learning (SCL), yaitu pembelajaran yang berpusat pada siswa.

Walaupun pembelajaran student centered learning (SCL) telah muncul sejak lama, penerapannya pada kegiatan belajar mengajar sesungguhnya terjadi secara berangsur-angsur. Di Indonesia student centered learning (SCL) masih menjadi topik yang populer pada saat ini terutama dikalangan pembelajaran tatap muka yang ditandai dengan muncul dan ramainya permintaan diskusi, ceramah, dan pelatihan tentang SCL. Pemikir 
seperti John Dewey, Jean Piaget, dan Vygostky yang karyanya terfokus pada bagaimana siswa belajar, bertanggung jawab atas gerak perubahan cara pembelajaran dari yang terpusat pada guru menjadi terpusat pada siswa, yaitu student centered learning (SCL). SCL berarti menempatkan siswa sebagai pusat dari kegiatan belajar. Pergerakan konsep tersebut didukung pula oleh penelitian mengenai bagaimanakerja otak manusiayang menyebutkan bahwa siswa belajar secara lebih baik dengan cara mengalami langsungdan mengontrol proses belajar tersebut.

Melaksanakan model SCL berarti guru perlu membantu siswa untuk menentukan tujuan yang dicapai, mendorong siswa untuk dapat menilai hasil belajarnya sendiri, membantu mereka untuk bekerja sama dalam kelompok, memastikan agar mereka mengetahui mengetahui bagaimana memanfaatkan semua sumber belajar yang tersedia.

Berikut ini beberapa pengertian SCL dari berbagai pendapat para ahli, yaitu:

a. Rogers (1983), SCL merupakan hasil dari transisi perpidahan kekuatan dalam proses pembelajaran, dari kekuatan guru sebagai pakar menjadi kekuatan siswa sebagai pembelajar. Perubahan ini terjadi setelah banyak harapan untuk memodifikasi atmosfer pembelajaran yang menyebabkan siswa menjadi pasif, bosan dan resisten.

b. Kember (1997), SCL merupakan sebuah kutub proses pembelajaran yang menekankan siswa sebagai pembangun pengetahuan sedangkan kutub yang lain adalah guru sebagai agen yang memberikan pengetahuan.

c. Harden dan Crosby (2000), SCL menekankan pada siswa sebagai pembelajar dan apa yang dilakukan siswa untuk sukses dalam belajar dibanding dengan apa yang dilakukan oleh guru.

Dari berbagai definisi tersebut dapat dipahami bahwa Student Centered Learning (SCL) adalah suatu model pembelajaran yang menempatkan peserta didik sebagai pusat dari proses belajar. Model pembelajaran ini berbeda dari model belajar InstructureCentered Learning yang menekankan pada transfer pengetahuan dari guru ke siswa yang relatif bersikap pasif.

Dalam menerapkan konsep Student Centered Leaning, siswa diharapkan sebagai peserta aktif dan mandiri dalam proses belajarnya, yang bertanggung jawab dan berinisiatif untuk mengenali kebutuhan belajarnya, menemukan sumber-sumber informasi untuk dapat menjawab kebutuhannya, membangun serta mempresentasikan pengetahuannya berdasarkan kebutuhan serta sumber-sumber yang ditemukannya. Dalam batas-batas tertentu siswa dapat memilih sendiri apa yang akan dipelajarinya.

Seiring dengan perkembangan zaman, maka proses belajar yang berpusat pada pengajar (teacher centered learning) dianggap sudah tidak memadai lagi, sehingga perlu adanya perubahan metode pembelajaran yang lebih berfokus pada peserta didik (student centered learning) dengan harapan peserta didik memiliki motivasi dalam diri sendiri untuk menentukan arah tujuan pembelajarannya. Pembelajaran student centered learning adalah model pembelajaran yang berpusat pada peserta didik, dimana peserta didik mampu untuk menjadi peserta didik yang aktif dan mandiri dalam proses belajarnya dan memiliki bertanggungjawab serta inisiatif untuk mengenali kebutuhan belajarnya dan mampu untuk menemukan sumber-sumber informasi tanpa tergantung pada orang lain dalam hal ini pengajar.

Pembelajaran yang berpusat pada peserta didik adalah proses belajar mengajar berdasarkan kebutuhan dan minat peserta didik. Model pembelajaran yang berpusat pada peserta didik dirancang untuk menyediakan sistem belajar yang fleksibel sesuai dengan kehidupan dan gaya belajar siswa. Lembaga pendidikan dan guru tidak berperan sebagai sentral melainkan hanya sebagai penunjang (Oemar Hamalik, 2004, h. 201) 
Student Centered Learning, yang menekankan pada minat, kebutuhan dan kemampuan individu, menjanjikan model belajar yang menggali motivasi intrinsik untuk membangun masyarakat yang suka dan selalu belajar. Model belajar ini sekaligus dapat mengembangkan kualitas sumber daya manusia yang dibutuhkan masyarakat seperti kreativitas, kepemimpinan, rasa percaya diri, kemandirian, kedisiplinan, kekritisan dalam berpikir, kemampuan berkomunikasi dan bekerja dalam tim, keahlian teknis, serta wawasan global untuk dapat selalu beradaptasi terhadap perubahan dan perkembangan.

Model pembelajaran SCL adalah pelaksanaan proses belajar-mengajar dengan sistem Cara Belajar Siswa Aktif atau SCL. Dengan SCL siswa akan bekerja dengan berbagai aktivitas dalam mempelajari bahan pembelajaran. Siswa akan terlatih untuk mempunyai tanggungjawab yang lebih besar dalam proses pembelajaran dan tertanam suatu kebiasaan belajar yang lebih bertanggungjawab.

Pada proses pembelajaran model SCL merupakan perpaduan antara metode ceramah dan diskusi dengan menekankan agar siswa telah belajar secara mandiri sebelum masuk kelas. Pembelajaran tidak dilakukan satu arah. Metode pengajaran bukan metode ceramah saja, atau diskusi saja, tetapi gabungan dari keduanya. Guru akan menyampaikan isi pelajaran dengan bantuan LCD projector. Siswa diberi penjelasan materi pelajaran, dan diminta untuk menjelaskan bagian dari isi pelajaran. Dengan demikian akan terjadi dialog antara siswa dengan guru. Siswa diberi kesempatan seluasluasnya untuk menyampaikan pendapat, bertanya atau mengkritik/berbeda pendapat, dan harus selalu siap sedia menjawab pertanyaan yang dilontarkan guru. Dalam hal ini guru harus pandai mengelola waktu, dengan baik agar materi pelajaran dapat selesai.

Dengan inovasi ini akan terjadi perubahan peran siswa dalam proses pembelajaran sebagai berikut:
1. Siswa ikut bertanggungjawab dalam proses pembelajaran

2. Siswa belajar bagaimana belajar secara mandiri

3. Siswa secara aktif mencari pengetahuan dan melakukan konstruksi dan pemahaman terhadap materi pembelajaran

Sedangkan guru akan berperan dalam:

1. Menyediakan berbagai cara dan bentuk untuk mengakses bahan pembelajaran

2. Bertindak sebagai fasilitator yang membantu siswa dalam mengkases dan memproses bahan pembelajaran

3. Memfasilitasi proses belajar aktif

4. Memberikan dukungan kepada siswa dalam belajar aktif untuk meningkatkan kemampuan siswa dalam menguasai pengetahuan

5. Meningkatkan motivasi dan semangat siswa untuk memajukan pelajaran dan meningkatkan kemampuannya untuk belajar secara mandiri (Pembelajaran SCL.2009/11/05).

Pembelajaran Student Centered Learning merupakan pembelajaran dengan menggunakan sepasang perspektif, yaitu fokus pada individu pembelajar (keturunan, pengalaman, perspektif, latar belakang, bakat, minat, kapasitas, dan kebutuhan) dengan fokus pada pembelajaran (pengetahuan yang paling baik tentang pembelajaran dan bagaimana hal itu timbul serta tentang praktek pengajaran yang paling efektif dalam meningkatkan tingkat motivasi, pembelajaran, dan prestasi bagi semua pembelajar.

Pembelajaran yang berpusat pada peserta didik (student centered learning) dalam penerapannya dapat memudahkan perancangan instruksi pembelajaran yang efektif untuk setiap siswa, memudahkan penyerapan materi bagi siswa serta dapat meningkatkan kemandirian maupun kemampuan komunikasi dan kolaborasi bagi siswa, dengan demikian model pembelajaran yang berbasis student centered learning adalah kunci keberhasilan dalam penerapan suatu proses pembelajaran yang 
dilaksanakan oleh lembaga pendidikan terkhusus oleh para pendidik (guru).

\section{KARAKTERISTIK PEMBELAJARAN BERBASIS STUDENT CENTERED LEAR- NING}

Beberapa karakteristik dari pembelajaran berbasis Student Centered Learning (SCL) yang menyangkut aspek dari pengajar, siswa, materi dan teknik penyampainnya, yaitu:

a. Pengajar berperan sebagai penunjang, dalam hal ini bertugas sebagai perantara pembelajaran yang membantu mengarahkan siswa, dan apabila perlu ikut dalam membantu siswa dalam mengembangkan materi yang ada.

b. Pengajar berwawasan luas dan bersifat terbuka terhadap masukan maupun kritikan yang membangun bagi siswanya.

c. Pengajar menggunakan cara penyampaian materi yang dianggap sesuai dengan kebutuhan dan kondisi siswa, dalam hal ini tidak menutup kemungkinan seorang pengajar menggunakan cara pengajaran yang berbeda untuk setiap kelas.

d. Siswa merupakan tokoh utama pembelajaran yang memiliki wewenang untuk menentukan apa saja yang akan dipelajari terkait dengan materi yang ada termasuk cara penyampaiannya.

e. Siswa merupakan tokoh yang aktif pada proses pembelajaran yang senantiasa memberikan gagasan, baik saran dan kritik. Mereka bukan hanya menerima materi dari pengajar melainkan juga ikut serta dalam merumuskan, mengembangkan dan memproses materi pembelajaran.

f. Siswa mampu untuk mengembangkan materi belajar secara mandiri, dimana saja, kapan saja, bukan hanya di kelas atau di tempat pengajar berada.

g. Siswa mampu merumuskan harapan mereka terhadap proses pembelajaran dan mengukur kinerja mereka sendiri.

h. Siswa saling berkolaborasi satu sama lain.

i. Siswa memantau pembelajarannya sendiri, sehingga mampu untuk merumuskan strategi pembelajaran yang tepat untuk mencapai hasil yang optimal.

j. Siswa termotivasi untuk mencapai sasaran yang telah ditetapkannya sendiri.

k. Siswa memilih anggota kelompoknya sendiri dan menemukan bagaimana cara bekerja dalam kelompok tersebut.

1. Materi pembelajaran bersifat sebagai arahan bukan patokan pembelajaran, sehingga pengajar dan siswa tidak hanya terpaku pada materi yang ada, namun kreatif untuk mengembangkannya secara berkelanjutan.

m. Pembelajaran adalah proses pencarian ilmu pengetahuan secara aktif atau proses perumusan ilmu bukan proses penangkapan ilmu semata.

n. Siswa membangun pengetahuannya sendiri melalui proses pembelajaran pribadi yang dilaluinya. Hubungan timbal balik antara siswa dengan komponen-komponen lain penyusun proses pembelajaran yang tercipta pada beberapa aktivitas, seperti skilled instructor, online curiculum, online asessment, communities, optimal textbook, projek and case studies, instruction multimedia, simulation, remote lab, handon skill exams, handon lab.

o. Menempatkan siswa sebagai subjek belajar, artinya siswa berperan aktif dalam setiap proses pembelajaran dengan cara menemukan dan menggali sendiri materi pelajaran.

p. Siswa yang mendominasi pembelajaran, sedangkan guru hanya sebagai fasilitator (mitra pembelajaran). 
q. Siswa belajar melalui kegiatan kelompok, seperti kegiatan kelompok, berdiskusi, saling menerima dan memberi.

r. Tujuan akhir dari proses pembelajran adalah kepuasan diri.

s. Siswa ikut bertanggung jawab dalam proses pembelajaran.

t. Siswa belajar bagaimana belajar secara mandiri.

u. Siswa secara aktif mencari pengetahuan dan melakukan konstruksi dan pemahaman terhadap materi pembelajaran.

Sedangkan karakteristik model pembelajaran berbasis student centered learning menurut Wina Sanjaya, yaitu:

a. Mengajar berpusat pada siswa bukan pada guru

b. Proses pembelajaran berlangsung dimana saja

c. Pembelajaran berorientasi pada pencapaian tujuan

d. Suasana berpusat pada mahasiswa

e. Mahasiswa yang mengendalikan proses

f. Mahasiswa yang bertanggung jawab

g. Pembelajaran bersifat kooperatif, kolaboratif, atau independen. Siswa harus saling bekerja sama. Siswa berkompetisi dengan kinerja mereka sebelumnya (Wina Sanjaya, 2007, h. 97-98)

\section{HAKIKAT MASALAH DALAM PEMBE- LAJARAN BERBASIS STUDENT CENTE- RED LEARNING}

Antara model pembelajaran konvensional dan model pembelajaran berbasis Student Centered Learning terdapat perbedaan. Perbedaan tersebut terletak pada kegiatan pembelajaran yang dilakukan. Kegiatan pembelajaran pada model pembelajaran konvensional adalah guru yang mendominasi kegiatan pembelajaran sedangkan siswa bersifat pasif, siswa ditempatkan sebagai objek belajar yang berperan sebagai penerima informasi secara pasif. Tujuan akhir dari kegiatan pembelajaran adalah mengharapkan nilai atau angka. Adapun tujuan yang ingin dicapai pada kegiatan pembelajaran konvensional adalah keberhasilan pembelajaran biasanya hanya diukur dari tes.

Kemudian kegiatan pembelajaran pada model pembelajaran berbasis Student Centered Learning adalah siswa yang mendominasi kegiatan pembelajaran, dalam hal ini siswa yang lebih aktif dalam melakukan proses pembelajaran sedangkan guru hanya sebagai fasilitator, siswa ditempatkan sebagai subjek belajar yang berperan dalam menemukan dan menggali sendiri materi pelajaran. Tujuan akhir kegiatan pembelajaran berbasis Student Centered Learning adalah mengharapkan kepuasan diri. Tujuan yang ingin dicapai adalah seluruh aspek perkembangan siswa, dengan demikian keberhasilan pembelajaran diukur melalui berbagai cara, misalnya dengan evaluasi proses, hasil karya siswa, penampilan, rekaman, observasi, wawancara, dan lain-lain. Kemudian mendorong siswa untuk terlibat secara aktif dalam membangun pengetahuan, sikap dan perilaku.

Hakikat masalah dalam pembelajaran berbasis student centered learning adalah adanya problematika pendidikan yang terjadi di Indonesia salah satunya adalah terdapatnya kesenjangan yang cukup besar antara pengetahuan yang dimiliki para siswa dengan sikap dan perilakunya. Seperti banyak siswa yang tahu/hafal materi pelajaran, tetapi tidak mampu mengaplikasikan pengetahuannya tersebut bagi peningkatan kualitas kehidupannya.

Jadi, pengetahuan menjadi sesuatu yang hanya dihafal saja, tapi tidak berpengaruh dalam kehidupannya dan pengetahuan hanya mampir sebentar dan kemudian menguap begitu saja, seolah tidak berbekas dalam kehidupan siswa. Untuk menciptakan tujuan pembelajaran yang diharapkan maka dilakukan inovasi (perubahan) baru yaitu dengan cara mengaktifkan siswa, maksudnya siswa lebih aktif aktivitas belajarnya 
dalam pembelajaran, sedangkan guru hanya sebagai fasilitator dan mengarahkan saja.

\section{TAHAPAN-TAHAPAN PEMBELAJARAN BERBASIS STUDENT CENTERED LEAR- NING}

\section{a. Tahap Pra Instruksional}

Tahap Pra Instruksional merupakan tahapan yang ditempuh guru pada saaat ia memulai proses pembelajaran. Langkahlangkah pada tahap ini, yaitu:

1. Guru mengucapkan salam

2. Guru dan siswa bersama-sama membaca surat pendek

3. Guru menanyakan keadaan siswa dan mencatat kehadiran siswa

4. Guru melakukan apersepsi dan motivasi

5. Guru memberikan kesempatankepada siswa untuk bertanya mengenai bahan pelajaran yang belum dikuasai dan pelajaran yang telah dipelajari sebelumnya

b. Tahap Instruksional

Tahap Instruksional merupakan tahapan pengajaran/tahapan inti, yakni tahapan memberikan bahan pembelajaran yang telah disusun guru pada hari sebelumnya. Langkah-langkah pada tahapan ini, yaitu:

1. Guru menuliskan tujuan pembelajaran

2. Guru mencatatkan atau menjelaskan pokok materi yang akan dipelajari

3. Guru menjelaskan kegiatan belajar yang akan dilakukan siswa

4. Guru menggunakan alat bantu

5. Guru menggunakan contoh-contoh yang konkret

6. Guru memberikan penguatan c. Tahap Evaluasi

Tahap Evaluasi merupakan tahapan penilaian dalam kegiatan pembelajaran. Tujuannya adalah untuk mengetahui tindakan keberhasilan tahapan kedua (instruksional).

1. Guru bersama siswa menyimpulkan pelajaran

2. Guru memberikan tes formartif

3. Guru menjelaskan dan memberitahu materi yang akan dipelajari berikutnya

4. Guru menutup pembelajaran dengan membaca Hamdalah dan Salam

Ketiga tahap pembelajaran di atas, merupakan satu rangkaian kegiatan yang terpadu, tidak dipisahkan satu sama lain. Guru dituntut untuk mampu dan dapat mengatur waktu dan kegiatan secara fleksibel, sehingga ketiga rangkaian tersebut diterima oleh peserta didik secara utuh. Di sinilah letak keterampilan guru dalam melaksanakan strategi mengajar.

Pada umumnya pelaksanaan pembelajaran mencakup tiga kegiatan, yakni:

1. Pembukaan

Pembukaan adalah kegiatan awal yang harus dilakukan guru untuk memulai atau membuka pelajaran. Membuka pembelajaran merupakan suatu kegiatan untuk menciptakan kesiapan mental dan menarik perhatian peserta didik secara optimal, agar mereka memusatkan diri sepenuhnya untuk belajar. Untuk kepentingan tersebut, guru dapat melakukan upaya-upaya sebagai berikut:

a. Menghubungkan kompetensi yang telah dimiliki peserta didik dengan materi yang akan disajikan.

b. Menyampaikan tujuan yang akan dicapai dan garis besar materi yang akan dipelajari.

c. Menyampaikan langkah-langkah kegiatan pembelajaran dan tugas-tugas yang harus diselesaikan untuk mencapai tujuan yang telah dirumuskan. 
d. Mendayagunakan media dan sumber belajar yang bervariasi sesuai dengan materi yang disajikan.

e. Mengajukan pertanyaan, baik untuk mengetahui pemahaman peserta didik terhadap pembelajaran yang telah berlalu maupun untuk menjaga kemampuan awal berkaitan dengan bahan yang akan dipelajari.

2. Pembentukan kompetensi

Pembentukan kompetensi peserta didik merupakan kegiatan inti pembelajaran, antara lain mencakup penyampaian informasi tentang materi pokok atau materi standar, membahas materi standar untuk membentuk kompetensi peserta didik, serta melakukan tukar pengalaman dan pendapat dalam membahas materi standar atau memecahkan masalah yang dihadapi bersama. Dalam pembelajaran peserta didik dibantu oleh guru untuk membentuk kompetensi, serta mengembangkan dan memodifikasi kegiatan pembelajaran, apabila kegiatan itu menuntut adanya pengembangan atau modifikasi.

Pembentukan kompetensi mencakup berbagai langkah yang perlu ditempuh oleh peserta didik dan guru sebagai fasilitator untuk mewujudkan standar kompetensi dan kompetensi dasar. Hal ini ditempuh melalui berbagai cara, bergantung kepada situasi, kondisi, kebutuhan, serta kemampuan peserta didik. Prosedur yang ditempuh dalam pembentukan kompetensi adalah sebagai berikut:

a. Berdasarkan kompetensi dasar dan materi standar yang telah dituangkan dalam Rencana Pelaksanaan Pembelajaran (RPP), guru menjelaskan standar kompetensi minimal yang harus dicapai peserta didik dan cara belajar untuk mencapai kompetensi tersebut.

b. Guru menjelaskan materi standar secara logis dan sistematis, materi pokok dikemukakan dengan jelas atau ditulis dipapan tulis. Memberi kesempatan peserta didik untuk bertanya sampai materi standar tersebut benar-benar dapat dikuasai.

c. Membagikan materi standar atau sumber belajar berupa hand out dan foto copy beberapa bahan yang akan dipelajari. Materi standar tersebut sebagian terdapat di perpustakaan.

d. Mambagikan lembaran kegiatan untuk setiap peserta didik. Lembaran kegiatan berisi tugas tentang materi standar yang telah dijelaskan oleh guru dan dipelajari oleh peserta didik.

e. Guru memantau dan memeriksa kegiatan peserta didik dalam mengerjakan lembaran kegiatan, sekaligus memberikan bantuan dan arahan bagi mereka yang menghadapi kesulitan belajar.

f. Setelah selesai diperiksa bersama-sama dengan cara menukar pekerjaan dengan teman lain, lalu guru menjelaskan setiap jawabannya.

g. Kekeliruan dan kesalahan jawaban diperbaiki oleh peserta didik. Jika ada yang kurang jelas, guru memberi kesempatan bertanya, tugas, atau kegiatan mana yang perlu penjelasan lebih lanjut (E. Mulyasa, 2009, h.180186)

3. Penutup

Penutup merupakan kegiatan akhir yang dilakukan guru untuk mengakhiri pembelajaran. Dalam kegiatan penutup ini guru harus berupaya unutuk mengetahui pembentukan kompetensi dan pencapaian tujuan pembelajaran, serta pemahaman peserta didik terhadap materi yang dipelajari, sekaligus mengakhiri kegiatan pembelajaran. Untuk itu guru dapat melakukan kegiatan-kegiatan sebagai berikut:

a. Menarik kesimpulan mengenai materi yang telah dipelajari.

b. Mengajukan beberapa pertanyaan untuk mengukur tingkat pencapaian tujuan dan keefektifan yang telah dilaksanakan. 
c. Menyampaikan bahan-bahan pendalaman yang harus dipelajari dan tugastugas yang harus dikerjakan sesuai dengan pokok bahasan yang telah dipelajari.

d. Memberikan posttes baik secara lisan, tulisan, maupun perbuatan (E. Mulyasa, 2009, h.180-186).

\section{PENDIDIKAN AGAMA ISLAM}

Marimba menyatakan pendidikan adalah bimbingan secara sadar oleh si pendidik terhadap perkembangan jasmani dan rohani si terdidik menuju terbentuknya kepribadian yang utama (Ahmad Marimba, 1986). Pendidikan berarti interaksi dalam diri individu dengan masyarakat sekitarnya baik dilihat dari segi kecerdasan atau kemampuan, minat maupun pengalaman. Mendidik adalah usaha atau tindakan yang dilakukan secara sadar dengan bantuan alat pendidikan untuk mencapai tujuan pendidikan, sehingga terbentuk manusia yang bertanggung jawab. Tujuan yang ingin dicapai adalah membawa si terdidik ke arah terbentuknya kepribadian yang utama, baik jasmani maupun rohani bagi perjalanan hidupnya dimasa yang akan datang. Dapat diambil kesimpulan, bahwa Pendidikan Agama Islam adalah suatu aktivitas atau usaha-usaha tindakan dan bimbingan yang dilakukan secara sadar dan sengaja serta terencana yang mengarah pada terbentuknya kepribadian anak didik yang sesuai dengan norma-norma yang ditentukan oleh ajaran agama.

Tujuan pendidikan agama Islam identik dengan tujuan agama Islam, karena tujuan agama adalah "agar manusia memiliki keyakinan yang kuat dan dapat dijadikan sebagai pedoman hidupnya yaitu untuk menumbuhkan pola kepribadian yang bulat dan melalui berbagai proses usaha yang dilakukan. Dengan demikian tujuan Pendidikan Agama Islam adalah suatu harapan yang diinginkan oleh pendidik Islam itu sendiri. Islam mempunyai dua tujuan, yaitu:

a. Tujuan keagamaan, maksudnya ialah beramal untuk akhirat sehingga ia menemui tuhannya yang telah memurnikan hak-hak Allah yang telah diwajibkan atasnya.

b. Tujuan ilmiah yang bersifat keduniaan, yaitu apa yang diungkapkan oleh pendidikan modern dengan tujuan kemanfaatan atau persiapan untuk hidup. Tujuan pendidikan islam yang paling utama ialah beribadah kepada Allah dan kesempurnaaan insani yang tujuannya kebahagiaan dunia akhirat.

Zakiyah Darajat mendefinisikan tujuan Pendidikan Agama Islam: membina manusia beragama berarti manusia yang mampu melaksanaakan ajaran-ajaran agama Islam dengan baik dan sempurna, sehingga tercermin pada sikap dan tindakan dalam seluruh kehidupannya, dalam rangka mencapai kebahagiaan dan kejayaan dunia dan akhirat yang dapat dibina melalui pengajaran agama yang intensif dan efektif.

Dari pendapat di atas dapat disimpulkan bahwa tujuan Pendidikan Agama Islam adalah sebagai usaha untuk mengarahkan dan membimbing manusia dalam hal ini peserta didik agar mereka mampu menjadi manusia yang beriman dan bertaqwa kepada Allah SWT, serta meningkatkan pemahaman, penghayatan, dan pengamalan mengenai agama Islam, sehingga menjadi manusia muslim, berakhlak mulia dalam kehidupan baik secara pribadi, bermasyarakat dan berbangsa dan menjadi insan yang beriman hingga mati dalam keadaan Islam, sebagaimana firman Allah SWT dalam al-Quran surat ali-Imran: 102, yang artinya: "Hai orangorang yang beriman, bertaqwalah kepada Allah sebenar-benar taqwa kepada-Nya, dan janganlah sekali-kali kamu mati melainkan dalam keadaan beragama Islam." (Q.S AliImran: 102)

Fungsi Pendidikan Agama Islam bagi anak adalah membentuk manusia yang beriman dan bertaqwa kepada Allah SWT, mempunyai akhlak yang luhur, berilmu pengetahuan dan memiliki keterampilan yang dapat disalurkan. Agama benar-benar berfungsi sebagai pengendali kepribadian dalam hidupnya di kemudian hari. Pendidikan agama harus diberikan sejak dini agar anak terbiasa melakukan ibadah dan menjalankan ajaran- 
ajaraan Islam dengan kesadarannya sendiri. (Zakiyah Darajat, 2001, h. 86)

Pendidikan Agama Islam juga berfungsi sebagai media untuk meningkatkan Iman dan Taqwa kepada Allah SWT, serta sebagai wahana pengembangan sikap keagamaan dengan mengamalkan apa yang telah didapat dari proses pembelajaran Pendidikan Agama Islam.

Zakiyah Darajat berpendapat bahwa dalam buku metodik khusus Pendidikan Agama Islam bahwa sebagai sebuah bidang studi di sekolah, pendidikan agama Islam mempunyai tiga fungsi, yaitu: Pertama, menumbuhkan rasa keimanan yang kuat. Kedua, menanamkan kebiasaan melakukaan amal ibadah, amal saleh dan akhlak yang mulia. Ketiga, menumbuhkan semangat untuk mengolah alam sekitar sebagai anugerah Allah SWT kepada manusia.

Dari pendapat di atas dapat diambil beberapa hal tentang fungsi Pendidikan Agama Islam yang dapat dirumuskan sebagai berikut:

a. Pengembangan, yaitu meningkatkan keimanan dan ketaqwaan siswa kepada Allah SWT yang ditanamkan dalam lingkup pendidikan keluarga.

b. Penyaluran, yaitu untuk menyalurkan peserta didik yang memiliki bakat khusus di bidag agama agar bakat tersebut dapat berkembang secara optimal sehingga dapat dimanfaatkan untuk dirinya sendiri dan dapat pula bermanfaat bagi orang lain.

c. Perbaikan, yaitu untuk memperbaiki kesalahan-kesalahan, kekurangan-kekurangan dan kelemahan-kelemahan peserta didik dalam keyakinan, pemahaman dan pengamalan ajaran Islam dalam kehidupan sehari-hari.

d. Pencegahan, yaitu menangkal hal-hal negatif dari lingkungannya atau dari budaya lain yang dapat membahayakan dirinya dan menghambat perkembangannya menuju mausia Indonesia seutuhnya.

e. Penyesuaian, yaitu untuk menyesuaikan diri dengan lingkungan, baik lingkungan fisik maupun lingkungan sosial dan dapat bersosialisasi dengan lingkungannya sesuai dengan ajaran Islam.

f. Sumber lain, yaitu memberikan pedoman hidup untuk mencapai kebahagiaan hidup di dunia dan akhirat (Ramayulis, 2005, h. 21-22).

Jadi dapat diambil kesimpulan bahwa fungsi pendIdikan Agama Islam adalah untuk membentuk manusia yang beriman dan bertaqwa kepada Allah SWT, mempunyai akhlak yang mulia serta hidup dengan panduan al-Quran dan sunnah yang merupakan pedoman hidup bagi umat Islam melalui pembelajaran yang diberikan.

\section{SIMPULAN}

Dalam pembelajaran Pendidikan Agama Islam, peranan dan fungsi pendidik sangat strategis. Apapun pemakaian dan penggunaan strategi pembelajarannya, hendaklah tetap berpegang pada nilai-nilai budaya, dalam hal ini adalah pemakaian strategi pembelajaran yang telah dirumuskan dan dipakai oleh penutan kita yaitu Rasulullah saw. Dengan tidak menghilangkan sepenuhnya peranan guru dalam kelas. Dengan kata lain, dalam proses pembelajaran Pendidikan Agama Islam, di samping pemakaian strategi-strategi yang berpusat pada siswa (Student Centered) dalam meningkatkan kinerja siswa bukan berarti melepaskan peranan guru. Artinya dalam pembelajaran Pendidikan Agama Islam hendaknya kedua strategi pembelajaran tersebut tetap dipakai. Student Centered sebagai langkah pemahaman atau penguasaan terhadap materi pelajaran dan pemberian pengalaman atau pelatihan kepada siswa (kognitif, afektif, psikomotorik) dengan aktivitas siswa yang tinggi, serta Teacher Centered sebagai langkah membina dan menanamkan nilai-nilai yang terkandung dalam materi pelajaran tersebut (Spiritual) dalam diri siswa.

Dalam konteks pendidikan Islam, semua aspek pendidikan dalam Islam terkait dengan nilai-nilai (value bound), yang menempatkan guru selain sebagai pentransfer pengetahuan yang dimilikinya juga sebagai pentransfer nilainilai moral spiritual yang dimilikinya ke arah pembentukan kepribadian anak didik. Penana- 
man dan penghayatan nilai-nilai Islam peserta didik tidak akan tercapai tanpa bantuan seorang pendidik.

Pada dasarnya kemungkinan anak untuk mengenal nilai-nilai memang ada, tetapi tanpa bimbingan yang tertentu (dari pendidik) tujuan pendidikan Islam tidak akan tercapai. Peserta didik mengenal dan menerima nilai-nilai melalui proses berangsur-angsur. Pertama-tama peserta didik mengenal baik-buruk melalui apa yang dilihat dan dikatakan pendidik. Dengan kata lain, gurulah yang mengajar dan mempraktikkan nilai-nilai ajaran Islam. Dengan selalu berpegang pada nilai-nilai budaya, yaitu proses pembelajaran Pendidikan Agama Islam yang dilakukan dengan strategi Student centered, tanpa menafikan Teacher centered, maka pendidikan Islam akan bisa menjawab tantangan zaman, yaitu pembentukan manusia yang kompeten dalam hidup dengan nilai moral yang tinggi.

Lebih lanjut, pada akhirnya pendidikan Islam akan menghasilkan manusia yang mulia, yaitu manusia yang cerdas mampu hidup dalam dunianya sekaligus berakhlakul karimah. Sebab manusia adalah makhluk yang mulia, dan kemuliaan itu terletak pada akhlaknya (iman dan taqwa). Sehingga kesejahteraan umum akan tercipta dengan adanya manusia yang berpendidikan serta berakhlakul karimah sebagai khalifah di bumi.

\section{DAFTAR RUJUKAN}

Darajat, 2001. Zakiyah, Metodologi Pengajaran Agama Islam, Jakarta: Bumi Aksara

Departemen Agama RI, 2000. Alqur'an dan Terjemahannya, Bandung: Diponegoro

Hamalik, Oemar, 2004. Proses Belajar Mengajar, Jakarta: Bumi Aksara

Hamalik, Oemar, 2009. Dasar-dasar Pengembangan Kurikulum, Bandung: Remaja Rosda-karaya

http://memuatratna.blogspot.com/ Sistem Pembelajaran SCL.2009/11/05. Sistem Pembelajaran.SCL.html http://fairuzelsaid.wordpress.com/2010/08/28/p endidikan-konsep-scl-student-centeredlearning/

http://docs.google.com/viewer/2011/10/12/pape r_skripsi_dik/efektivitas penggunaan metode pembelajaranstudent centered learning berbasis classroom blogging untuk meningkatkan hasil belajar Siswa SMA

Marimba, Ahmad D. 1986. Pengantar Filsafat Pendidikan Islam, Bandung: PT.AlMa'arif

Mulyasa, E., 2009. Implementasi Kurikulum Tingkat Satuan Pendidikan Kemandirian Guru dan Kepala Sekolah, Jakarta: Bumi Aksara

Ramayulis, 2005. Metodologi Pendidikan Agama Islam, Jakarta: Kalam Mulia

Rusman, 2010. Model-model Pembelajaran, Jakarta: PT Raja Grafindo Persada

Sanjaya, Wina, 2007. Strategi Pembelajaran Berorientasi Standar Proses Pendidikan, Jakarta: Kencana

Shihab, M.Quraish, 2002. Tafsir Al-Misbah Pesan, Kesan dan Keserasian al-Quran, Jakarta: Lentera Hati

Undang-undang No.20 Tahun 2003, Sistem Pendidikan Nasional (SISDIKNAS), Jakarta: Sinar Grafika 